\title{
Secretion of Proinflammatory Cytokines by Epithelial Cells in Response to Chlamydia Infection Suggests a Central Role for Epithelial Cells in Chlamydial Pathogenesis
}

\author{
Stephanie J. Rasmussen, ${ }^{\star}$ Lars Eckmann, ${ }^{\S}$ Alison J. Quayle," Li Shen, "You-Xun Zhang, "Deborah J. Anderson, \\ Joshua Fierer, ${ }^{\star \star}$ Richard S. Stephens, ${ }^{\star \star}$ and Martin F. Kagnoff ${ }^{\S}$ \\ *Francis I. Proctor Foundation, University of California, San Francisco, San Francisco, California 94143; ${ }^{*}$ Program in Infectious \\ Diseases, School of Public Health, University of California, Berkeley, Berkeley, California 94720; ${ }^{\S}$ Laboratory of Mucosal Immunology, \\ Department of Medicine, University of California, San Diego, La Jolla, California 92093; "Department of Obstetrics, Gynecology and \\ Reproductive Biology, Brigham and Women's Hospital, Harvard Medical School, Boston, Massachusetts 02115, "Taxwell Finland \\ Laboratory for Infectious Diseases, Boston City Hospital and Boston University School of Medicine, Boston, Massachusetts 02118; \\ and **Division of Infectious Diseases, Department of Veterans Affairs Medical Center, San Diego, California 92161
}

\begin{abstract}
Chlamydia species infect epithelial cells at mucosal surfaces, and are major causes of sexually transmitted diseases. Infection is characterized by inflammation which is exacerbated upon reinfection, ultimately leading to tissue damage and scarring. Although central for the development of disease manifestations, little is known about the mechanisms that initiate and sustain the inflammatory response to Chlamydia. Infection of cervical and colonic epithelial cells with Chlamydia trachomatis and Chlamydia psittaci is shown in the present studies to upregulate mRNA expression and secretion of the proinflammatory cytokines IL-8, GRO $\alpha$, GM-CSF, and IL-6. In contrast to the rapid, but transient, cytokine induction following infection with other invasive bacteria, the epithelial cytokine response to Chlamydia was delayed until 20-24 h after infection, persisted throughout the chlamydial growth cycle $(2-4 \mathrm{~d})$, and required bacterial protein synthesis. Moreover, epithelial cell lines and primary endocervical epithelial cells released IL-1 $\alpha$ after Chlamydia infection, and increased secretion of the proinflammatory cytokines could be inhibited by antiIL-1 $\alpha$. This suggests that IL- $1 \alpha$, released following lysis of infected epithelial cells, may amplify the inflammatory response by stimulating additional cytokine production by noninfected neighboring cells. These findings suggest a novel pathophysiologic concept wherein the acute host response to Chlamydia at mucosal surfaces is primarily initiated and sustained by epithelial cells, the first and major targets of chlamydial infection. (J. Clin Invest. 1997. 99:7787.) Key words: inflammation - mucosa - IL-8 - IL-1 $\alpha$ • Chlamydia trachomatis
\end{abstract}

S.J. Rasmussen and L. Eckmann contributed equally to this work.

Address correspondence to Lars Eckmann, Laboratory of $\mathrm{Mu}-$ cosal Immunology, University of California, San Diego, Department of Medicine 0623D, 9500 Gilman Drive, La Jolla, CA 92093-0623. Phone: 619-534-0683; FAX: 619-534-5691; E-mail: leckmann@pop mail.ucsd.edu

Received for publication 26 August 1996 and accepted in revised form 25 October 1996.

The Journal of Clinical Investigation

Volume 99, Number 1, January 1997, 77-87

\section{Introduction}

Chlamydiae are intracellular bacterial pathogens that cause a spectrum of clinically important diseases in humans. Chlamydia trachomatis is the most common cause of sexually transmitted disease, and is the causative agent of trachoma, the leading cause of preventable blindness (1). Moreover, chlamydial genital tract infection is an important risk factor for HIV transmission $(2,3)$. Chlamydia psittaci, which predominantly infects animals and causes a variety of respiratory, gastrointestinal, and urogenital diseases, also can cause pneumonia in humans (4).

Chlamydial infection is initiated by the extracellular elementary body $(\mathrm{EB})^{1}$ which attaches to and invades epithelial cells at mucosal surfaces (5). Within 8 to $12 \mathrm{~h}$ after invasion, EBs develop into the metabolically active reticulate bodies (RBs). RBs divide by binary fission inside a host-derived endosome that eventually occupies much of the host cell cytoplasm (then termed the chlamydial inclusion) (6). RBs reorganize into EBs 18-30 h after invasion of host cells, and infected cells begin to lyse and release infectious EBs at $48-72 \mathrm{~h}$ postinfection (p.i.).

Little is known about the pathogenesis of acute human chlamydial infections, and our knowledge of acute infection has been derived largely from animal models. The host response to primary chlamydial infection at mucosal surfaces occurs within 1-2 $\mathrm{d}$ of infection and is characterized by inflammation and mucosal infiltration with neutrophils and small numbers of monocytes (7). In animal models, the host response can control the infection, i.e., eliminate or substantially reduce the bacterial load (8-11). Both innate and acquired immunity appear to contribute to this outcome. Thus, neutrophils are recruited in large numbers to the site of infection, and are capable of killing accessible EBs, probably due to efficient fusion of lysosomes with Chlamydia-containing phagosomes, and release of myeloperoxidase and oxidants $(12,13)$. In addition, $\mathrm{T}$ cells accumulate at the site of Chlamydia infection and play a critical role in controlling the infection $(8,14)$, whereas $\mathrm{B}$ cells do not appear to be important for resolving infection in some models (15). In most cases, the host response to primary infection is transient and not associated with long-term tissue damage (7).

1. Abbreviations used in this paper: $\mathrm{EB}$, elementary body; IFU, inclusion-forming unit; p.i., postinfection; RB, reticulate body; RT, reverse transcription; $\mathrm{SN}$, supernatant. 
During reinfection or reactivation of a persistent infection, the initial inflammatory response occurs with a similar magnitude, whereas T cells infiltrate more rapidly and in larger numbers compared with the host response to a primary infection. The recurrent inflammatory reaction ultimately culminates in fibrosis and scarring, which can lead to blindness, tubal infertility, ectopic pregnancy, and chronic pelvic pain $(10,16)$. The specific pathways that underlie this tissue damaging response to infection are not known. Chlamydial heat shock proteins have been proposed to be involved in inducing inflammation at the site of infection (17), but this proposal is controversial $(18,19)$.

Epithelial cells at mucosal surfaces can secrete chemoattractant and proinflammatory cytokines in response to infection with pathogenic bacteria, suggesting that these cells act as an early warning system for immune and inflammatory cells in the underlying mucosa (20). The epithelial cytokine response to pathogenic bacteria depends on several factors, including the site of infection and the specific pathogen. For example, some noninvasive pathogenic bacteria, such as Pseudomonas aeruginosa $(21,22)$, uropathogenic Escherichia coli (23), and Helicobacter pylori $(24,25)$, induce proinflammatory cytokine secretion by epithelial cells at sites that normally harbor few or no bacteria, e.g., lungs, bladder, and stomach. In contrast, bacterial invasion appears to be required for epithelial cytokine induction at sites which are physiologically exposed to an abundant bacterial flora, i.e., the colon, because only invasive bacteria induce cytokine secretion by colon epithelial cells (26-28). Furthermore, toxins released by some pathogenic bacteria may play an additional role in inducing or modulating epithelial cytokine responses $(29,30)$.

In the present studies, the concept of epithelial cells as an important component of the early host response to infection with pathogenic bacteria was applied to understanding the pathogenesis of chlamydial disease. We show that in vitro infection of cervical and colonic epithelial cells with Chlamydia induces the secretion of an array of proinflammatory cytokines that have chemoattractant and proinflammatory functions, including IL-8, GRO $\alpha$, GM-CSF, IL-6, and IL-1 $\alpha$. Moreover, in contrast to invasion by other bacteria that induce a rapid but transient proinflammatory cytokine response upon entry (26), chlamydial invasion alone was not sufficient for this response. Rather, intracellular chlamydial growth was required, and the epithelial cytokine response was sustained throughout the chlamydial growth cycle. These findings suggest a new basis for understanding the mechanism of chlamydial pathogenesis, wherein the acute host inflammatory response to Chlamydia is mediated by the local production of proinflammatory cytokines from infected epithelial cells.

\section{Methods}

Chlamydial strains. C. trachomatis serovar $\mathrm{L} 2 / 434 / \mathrm{Bu}$ was propagated in L929 suspension cultures, C. trachomatis serovars D/UW3/ Cx and I/UW12/Ur, and C. psittaci AP1 were propagated in L929 cell monolayers, as described previously (31). Briefly, cultures were grown in RPMI growth medium (RPMI 1640 medium supplemented with $10 \%$ heat-inactivated FCS, $60 \mu \mathrm{g} / \mathrm{ml}$ vancomycin, and $10 \mu \mathrm{g} / \mathrm{ml}$ gentamicin) at $37^{\circ} \mathrm{C}$ in $95 \%$ air $/ 5 \% \mathrm{CO}_{2}$. Cultures infected with $C$. trachomatis L2 or C. psittaci AP1 were grown for $48 \mathrm{~h}$, and those infected with C. trachomatis serovars D or I for $72 \mathrm{~h}$, before harvesting. Infected monolayers were detached by scraping, and then pelleted and sonicated to lyse the host cells. Cell debris was removed by differ- ential centrifugation as described previously (31). Chlamydial EBs were pelleted, resuspended in isotonic sucrose-phosphate-glutamate buffer (31), and frozen at $-80^{\circ} \mathrm{C}$. Infectious titers were determined by titration on L929 cell monolayers and staining with a FITC-labeled monoclonal antibody against chlamydial LPS (Meridian Diagnostics, Inc., Cincinnati, $\mathrm{OH}$ ), and are expressed in inclusion-forming units (IFUs).

Cell lines and primary endocervical epithelial cells. The following human cell lines were obtained from the American Type Culture Collection (Rockville, MD): HeLa cervix epitheloid carcinoma cells (CCL 2), SiHa cervix squamous carcinoma cells (HTB 35), HT-29 colon adenocarcinoma cells (HTB 38), and SW620 colon adenocarcinoma cells (CCL 227). Cells were grown in RPMI growth medium at $37^{\circ} \mathrm{C}$ in $95 \%$ air $/ 5 \% \mathrm{CO}_{2}$. The number of viable cells in the monolayers was determined by trypan blue dye exclusion following detachment of the monolayers from the culture plates with trypsin/EDTA.

Endocervix was obtained as discard material from hysterectomies performed for uterine leiomyomas of premenopausal women. Collection was approved by the Brigham and Women's Hospital Institutional Review Board. The majority of stromal tissue was removed from each specimen, and the tissue cut into $3 \times 3 \mathrm{~mm}^{2}$ pieces. Explants were washed twice with HBSS containing gentamicin $(1 \mu \mathrm{g} / \mathrm{ml})$ and amphotericin B $(50 \mu \mathrm{g} / \mathrm{ml})$, and placed in 12-well plates with the epithelial side down. After a 30-min incubation period to allow attachment, serum-free keratinocyte growth medium (Clonetics, San Diego, CA) was added to the wells. Medium was replaced every $4 \mathrm{~d}$, and epithelial cell outgrowth was seen within $7 \mathrm{~d}$. When cultures were approximately $60 \%$ confluent (after 3-4 wk), cells were detached using trypsin/EDTA, and subcultured onto 13-mm glass coverslips in 24-well plates (Thermanox; Nunc, Inc., Naperville, IL). Infection experiments were performed 24-96 h after subculture when cells were approximately $80 \%$ confluent. The epithelial cell origin of the primary cultures was confirmed by staining with a cytokeratin-specific antibody (ICN Pharmaceuticals, Costa Mesa, CA), and the absence of leukocytes was verified by the lack of staining with an antibody specific for leukocyte common antigen, CD45 (Dako Corp., Carpinteria, CA).

Infection protocol. Epithelial cells were seeded into 24-well plates at a density of $1-2 \times 10^{5}$ cells/well, and cultured for $24 \mathrm{~h}$. Monolayers were washed twice with HBSS and infected with a range of inocula (0.02-1000 IFUs/cell in $200 \mu \mathrm{l} /$ well) diluted in isotonic sucrose-phosphate-glutamate buffer. Plates were placed on a rocker for $2 \mathrm{~h}$ at room temperature. The inoculum was aspirated, the monolayer was washed twice with HBSS, and $500 \mu l$ growth medium was added to each well. Cultures were incubated at $37^{\circ} \mathrm{C}$ for up to $5 \mathrm{~d}$. In some experiments, supernatants were removed from parallel cultures at different times after infection to determine cumulative cytokine secretion. In other experiments, cytokine secretion from individual monolayers over 24-h periods was measured by replacing the supernatants with fresh media every $24 \mathrm{~h}$. Supernatants were stored at $-80^{\circ} \mathrm{C}$ until tested.

Cytokine assays. Cytokine concentrations in the culture supernatants were determined by ELISA. The following pairs of capturing and detecting antibodies were used: goat anti-human IL-8 (R \& D Systems Inc., Minneapolis, MN) and rabbit anti-human IL-8 (Endogen, Inc., Cambridge, MA); goat anti-human GRO $\alpha$ (R \& D Systems) and monoclonal mouse anti-human GRO $\alpha$ (R \& D Systems); goat anti-human IL-6 (R \& D Systems) and rabbit anti-human IL-6 (Endogen); goat anti-human IL-1 $\alpha$ (R \& D Systems) and monoclonal mouse anti-human IL-1 $\alpha$ (Genzyme Corp., Cambridge, MA). As secondary antibodies, peroxidase-labeled goat anti-rabbit immunoglobulin $\gamma$ and light chains (Biosource International, Camarillo, CA), and peroxidase-labeled goat anti-mouse $\operatorname{IgG}(\gamma$-chain specific; Sigma Chemical Co., St. Louis, MO) were used. The respective recombinant human cytokines were purchased from R \& D Systems and were used as standards. The ELISAs for IL-8, GRO $\alpha$, IL-6, and IL- $1 \alpha$ were sensitive to $30 \mathrm{pg} / \mathrm{ml}$ of the respective recombinant cytokine. The ELISA for human GM-CSF (Cytoscreen; Biosource International) was sensitive to $10 \mathrm{pg} / \mathrm{ml}$. 
$R N A$ extraction and reverse transcription (RT)-PCR analysis of cytokine $m R N A$ levels. Total cellular RNA was extracted from epithelial cells using an acid guanidinium thiocyanate-phenol-chloroform method (28). Qualitative RT-PCR analysis and quantitative RT-PCR analysis using internal RNA standards of mRNA levels for human IL-8, GRO $\alpha$, GM-CSF, IL-6, IL- $1 \alpha$, TGF $\beta 1$, and $\beta$-actin was performed as described previously (28). This method was sensitive to $<10^{4}$ mRNA molecules/ $\mu \mathrm{g}$ total RNA.

Statistical analysis. The statistical significance of the differences in cytokine secretion from control and infected cultures was determined by two-tailed $t$ test assuming unequal variances between groups. Significance levels are indicated in the figure and table legends.

\section{Results}

C. trachomatis infection induces IL-8 secretion by HeLa cervical epithelial cells. Acute chlamydial infections are characterized by intense inflammation and infiltration of the mucosa predominantly with neutrophils, but also other inflammatory cells (7). Little is known about the signals responsible for this response. We asked whether chlamydial infection of epithelial cells, which are the major targets of infection, induces the production and secretion of chemoattractant and proinflammatory cytokines by the infected cells. HeLa epithelial monolayers were infected with $C$. trachomatis, and cultured for up to $5 \mathrm{~d}$ to encompass at least one entire cycle of chlamydial development. The initial studies focused on the potent neutrophil chemoattractant IL-8. Infection of HeLa cells with $C$. trachomatis increased IL-8 secretion by $>50$-fold compared with mock infected control cells (Fig. $1 A$ ). Increased levels of IL-8 in the culture supernatants were first detected $20-24 \mathrm{~h}$ p.i., reached a maximum $3 \mathrm{~d}$ p.i., and remained elevated thereafter. Moreover, infection with as few as 1 IFU C. trachomatis per 10 epithelial cells increased IL- 8 secretion when measured $3 \mathrm{~d}$ after infection (Fig. $1 \mathrm{~B}$ ). In contrast, no increase in IL-8 secretion was detected early after infection (6-10 h p.i.), even if a high multiplicity of infection was used, e.g., up to 1,000 IFUs/ cell (Fig. $1 B$ ).

The time course of the epithelial IL-8 response to C. trachomatis depends on the infectious dose. Because cumulative IL-8 secretion reached a maximum $3 \mathrm{~d}$ after $C$. trachomatis infection and cell lysis began to occur at this time, the relation of IL-8 secretion rates to the number of viable cells in the infected cultures was characterized. For these experiments, culture supernatants were harvested and replaced every $24 \mathrm{~h}$ for $4 \mathrm{~d}$ after infection, and IL-8 concentrations were determined for each 24-h period. In parallel, the number of viable cells present in the monolayers was determined at the end of each 24-h period. As shown in Fig. 2, most of the increase in IL-8 secretion occurred before substantial cell lysis was noted. At later times after infection ( $>3 \mathrm{~d})$, IL-8 secretion decreased and this was paralleled by lysis of the majority of host cells, suggesting that the decrease in IL- 8 secretion was caused by the decrease in the number of viable cells in the infected monolayers.

The time course of increased IL- 8 secretion and cell lysis was dependent on the dose of $C$. trachomatis in the inoculum (Fig. $2 A$ ). At the highest inoculum used ( $\sim 2$ IFUs/cell), maximal IL-8 secretion was observed 2 to $3 \mathrm{~d}$ p.i., whereas at the lowest inoculum (approximately 0.02 IFUs/cell), increased IL-8 secretion was not observed until after $3 \mathrm{~d}$ after infection, and maximal IL-8 secretion not until the end of the 4-d observation period. Despite a trend towards earlier IL- 8 secretion at higher
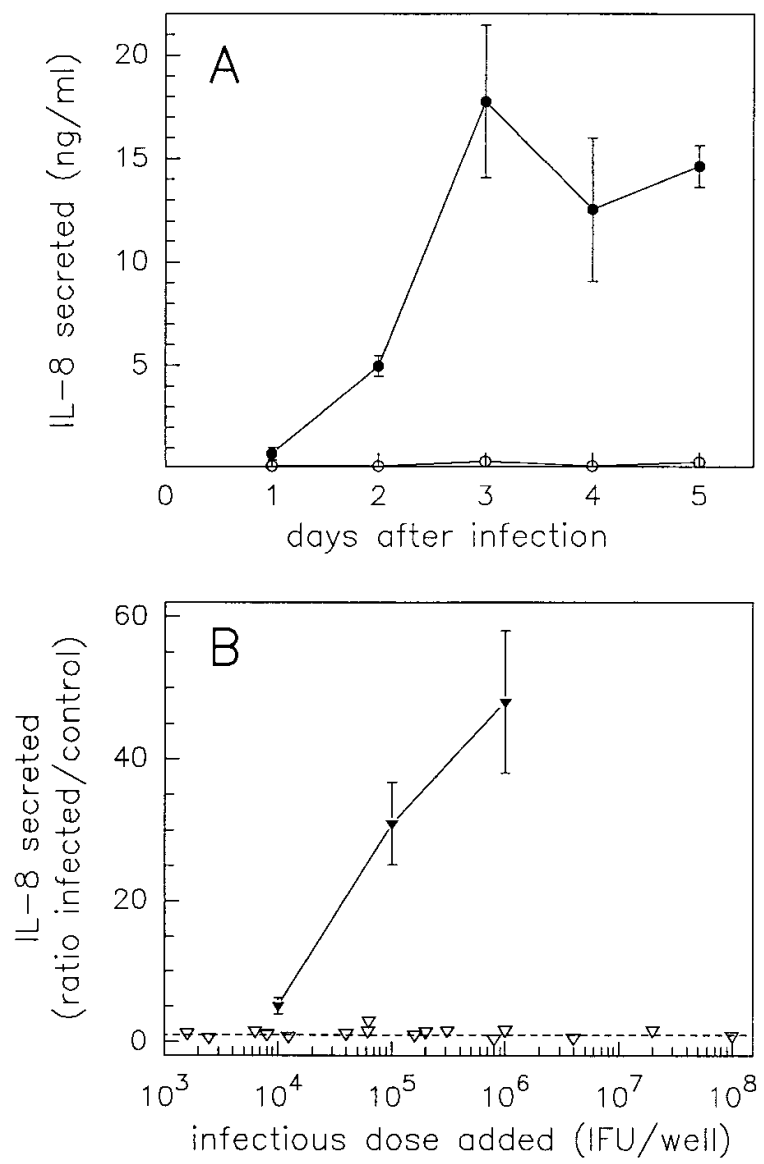

Figure 1. Increased IL-8 secretion by HeLa cells in response to infection with $C$. trachomatis. $(A)$ Time course of cumulative IL-8 secretion following $C$. trachomatis infection. Monolayers of HeLa cells in 24-well plates were infected with $1.0 \times 10^{6} \mathrm{IFUs} /$ well of $C$. trachomatis (serovar L2), and incubated for $2 \mathrm{~h}$ to allow invasion to occur. Monolayers were washed to remove nonadherent bacteria, and cultures were further incubated for up to $5 \mathrm{~d}$. During this period, supernatants from replicate cultures were collected at the indicated times, and IL- 8 concentrations were determined by ELISA for C. trachomatis-infected cultures $(\bullet)$, and for mock infected control cultures $(\bigcirc)$. Data points represent means \pm SD of the results of triplicate cultures from a representative experiment. Values of infected cultures were significantly increased compared with controls at all time points $(P \leq$ $0.05)$. A second experiment yielded IL-8 levels of 1.7 and $52.0 \mathrm{ng} / \mathrm{ml}$ in control and infected cultures, respectively, $72 \mathrm{~h}$ after infection. (B) Relationship of $C$. trachomatis inoculum size and cumulative IL-8 secretion. HeLa cell monolayers (containing approximately $1.0 \times 10^{5}$ cells/well) were infected for $2 \mathrm{~h}$ with the indicated doses of $C$. trachomatis (serovar L2), washed, and further incubated for 4-8 h $(\nabla)$, or $72 \mathrm{~h}(\boldsymbol{\nabla})$. Data are expressed as ratio of the IL-8 levels in C. trachomatis-infected cultures to that in mock infected control cultures. Data from cultures incubated for the shorter period (e.g., 4-8 h) are results from individual wells in 4 separate experiments, while data points from the 72 -h cultures represent means \pm SD of the results of triplicate wells from a representative experiment. The dashed line is a visual aid to show IL-8 levels in control cultures. Values of the cultures infected for $72 \mathrm{~h}$ were significantly increased compared with controls at all three inocula $(P \leq 0.05)$.

inocula, no increase in IL-8 secretion was observed early after infection (6-10 h p.i.), even at very high inocula (Fig. $1 B$ ). In contrast to the effect of the inoculum dose on the time of maximal IL- 8 secretion, the inoculum dose had a minor effect on 

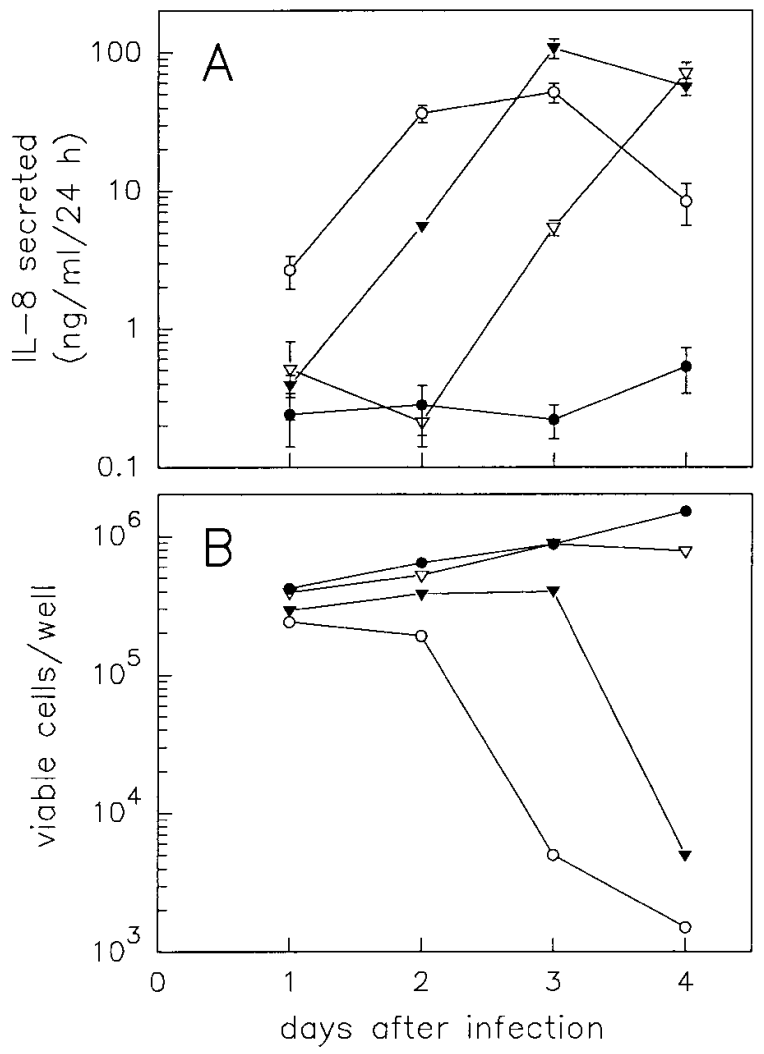

Figure 2. The time of maximal IL-8 secretion depends on the C. trachomatis inoculum size. HeLa cell monolayers in 24-well plates were infected for $2 \mathrm{~h}$ with $3.6 \times 10^{5}(\bigcirc), 3.6 \times 10^{4}(\boldsymbol{\nabla})$, or $3.6 \times 10^{3}(\nabla) C$. trachomatis (serovar L2) per well, corresponding to a multiplicity of infection of 2, 0.2, and $0.02 \mathrm{IFUs} /$ cell, because monolayers contained, on average, $1.8 \times 10^{5}$ cells/well. Mock-infected cultures $(\bullet)$ were used as controls. After infection, monolayers were washed, and cultures were further incubated for $4 \mathrm{~d}$, during which supernatants were collected and replaced with fresh media every $24 \mathrm{~h}$. (A) IL-8 secretion. IL- 8 concentrations in the $24 \mathrm{~h}$-supernatants were determined by ELISA. Data points represent means \pm SD of the results of triplicate cultures from one representative out of a total of four experiments. Values of infected cultures were significantly increased $(P \leq$ $0.05)$ compared with controls at all time points for the high and medium inoculum, and at days 3 and 4 for the low inoculum. (B) Viable cell numbers. The number of viable epithelial cells in the cultures was determined at the indicated times by trypan blue staining of single cell suspensions obtained after detaching the monolayers with trypsin/EDTA. Values represent the means of triplicate cultures.

the maximal levels of IL-8 secretion observed during the 4-d period of the experiment, because these were comparable at the three inoculum doses tested, i.e., over a 100 -fold inoculum range (Fig. $2 A$ ).

Increased secretion and $m R N A$ levels of an array of proinflammatory cytokines in HeLa cervical epithelial cells infected with C. trachomatis. We next asked whether proinflammatory cytokines other than IL-8 were upregulated in response to $C$. trachomatis infection of epithelial cells. As shown in Table I, infection of HeLa cells with C. trachomatis increased secretion of GRO $\alpha$, GM-CSF, and IL-6 by > 70-fold compared with controls, as determined $3 \mathrm{~d}$ after infection. Moreover, a threeto fourfold increase in the levels of IL-1 $\alpha$ was also detected in the supernatants of C. trachomatis-infected HeLa cells. In-
Table I. Increased Cytokine Secretion by HeLa Cells Infected with C. trachomatis*

\begin{tabular}{lccc}
\hline & \multicolumn{2}{c}{ Cytokines secreted $(\mathrm{ng} / \mathrm{ml})^{\ddagger}$} & \\
\cline { 2 - 3 } Cytokine & Control & + C. trachomatis L2 & $\begin{array}{c}\text { Ratio } \\
\text { Infected/Control }\end{array}$ \\
\hline IL-8 & $0.11 \pm 0.01$ & $33.22 \pm 2.10^{\S}$ & 302 \\
GRO $\alpha$ & $0.06 \pm 0.01$ & $9.32 \pm 0.30^{\S}$ & 155 \\
GM-CSF & $<0.01$ & $0.71 \pm 0.07^{\S}$ & $>71$ \\
IL-6 & $0.13 \pm 0.01$ & $12.51 \pm 0.51^{\S}$ & 96 \\
IL-1 $\alpha$ & $<0.03$ & $0.11 \pm 0.02^{\S}$ & $>3.6$ \\
\hline
\end{tabular}

*Monolayers of HeLa cells in 24-well plates were infected with approximately $1 \mathrm{IFU} /$ cell $C$. trachomatis L2 for $2 \mathrm{~h}$, after which monolayers were washed and further incubated for $2 \mathrm{~d}$. Medium was removed, fresh medium was added, and cultures were incubated for an additional $24 \mathrm{~h}$. Culture supernatants were collected, and cytokine concentrations were determined by ELISA. ${ }^{*}$ Results are means \pm SD of the values of triplicate cultures from one experiment. A second experiment showed comparable results, e.g., ratios of cytokine secretion in infected cultures to controls were 273, 84, > 334, and 77 for IL-8, GRO $\alpha$, GM-CSF, and IL-6, respectively. ${ }^{8}$ Values are significantly different from the respective controls $(P \leq 0.005$, except IL-1 $\alpha$ for which $P \leq 0.05)$.

creased secretion of IL-8, GRO $\alpha$, GM-CSF, IL-6, and IL- $1 \alpha$ in response to $C$. trachomatis infection was accompanied by increased mRNA levels for these cytokines, as determined $2 \mathrm{~d}$ after infection of HeLa cells with 1 IFU/cell (Table II). In contrast, mRNA levels for TGF $\beta 1$, a cytokine with known antiinflammatory activity (32), and the housekeeping gene $\beta$-actin were not affected, or decreased, after chlamydial infection of HeLa cells (Table II). As shown in a time course analysis, mRNA levels for IL- 8 and IL-1 $\alpha$ increased within $24 \mathrm{~h}$ after infection of HeLa cells, and reached a maximum $2 \mathrm{~d}$ after infection (Fig. 3).

Different chlamydial strains induce IL-8 secretion by various cultured human cervical and colon epithelial cell lines. In addition to $C$. trachomatis L2, we tested the ability of two other C. trachomatis strains representative of another C. trachomatis biovar (serovars I and D) and of C. psittaci (AP1) to induce IL-8 secretion by HeLa epithelial cells. As shown in Ta-

Table II. Increased Cytokine mRNA Levels in C. trachomatisinfected HeLa Cells*

\begin{tabular}{|c|c|c|c|}
\hline \multirow[b]{2}{*}{ Cytokine } & \multicolumn{2}{|c|}{$\begin{array}{c}\text { Number of mRNA molecules/ } \mu \mathrm{g} \text { cellular } \\
\text { RNA }\end{array}$} & \multirow{2}{*}{$\begin{array}{c}\text { Ratio } \\
\text { Infected/Control }\end{array}$} \\
\hline & Control & + C. trachomatis $\mathrm{L} 2$ & \\
\hline IL-8 & $3.5 \times 10^{4}$ & $2.3 \times 10^{7}$ & 657 \\
\hline GRO $\alpha$ & $4.0 \times 10^{4}$ & $1.1 \times 10^{6}$ & 28 \\
\hline GM-CSF & $<10^{4}$ & $2.7 \times 10^{6}$ & $>270$ \\
\hline IL-6 & $7.5 \times 10^{4}$ & $2.6 \times 10^{6}$ & 35 \\
\hline IL-1 $\alpha$ & $1.9 \times 10^{5}$ & $1.9 \times 10^{6}$ & 10 \\
\hline TGFß1 & $7.0 \times 10^{5}$ & $9.0 \times 10^{5}$ & 1.3 \\
\hline B-actin & $1.1 \times 10^{8}$ & $2.5 \times 10^{7}$ & 0.23 \\
\hline
\end{tabular}

*Monolayers of HeLa cells in $75-\mathrm{cm}^{2}$ flasks were infected with approximately $1 \mathrm{IFU} /$ cell of $C$. trachomatis $\mathrm{L} 2$ for $2 \mathrm{~h}$, washed, and further incubated for $48 \mathrm{~h}$. Total cellular RNA was extracted, and levels of mRNA transcripts were determined by quantitative RT-PCR using internal RNA standards, as described in Methods. 


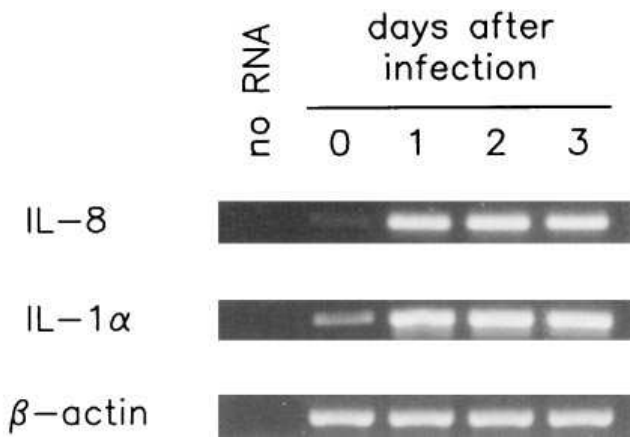

B

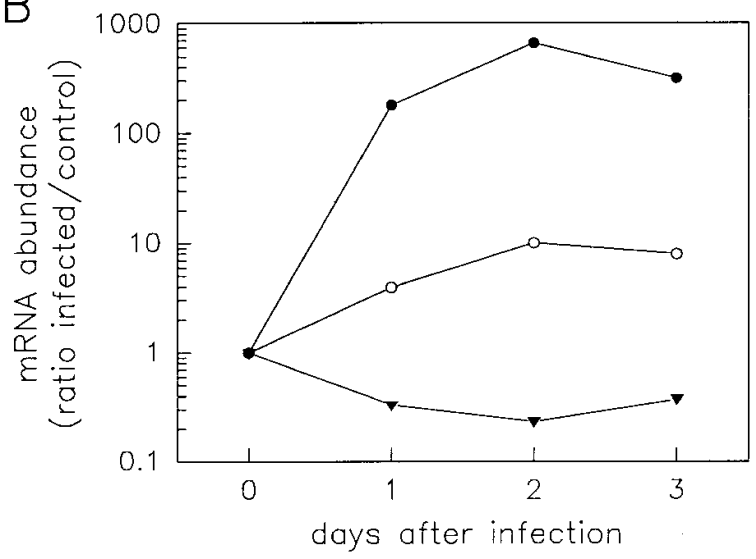

Figure 3. Time course of increased IL- 8 and IL- $1 \alpha$ mRNA levels in HeLa cells after $C$. trachomatis infection. HeLa cell monolayers in 75$\mathrm{cm}^{2}$ flasks were infected for $2 \mathrm{~h}$ with $\sim 1 \mathrm{IFU} /$ cell of $C$. trachomatis (serovar L2), washed, and further incubated for up to $72 \mathrm{~h}$. Total RNA was extracted at the indicated times after infection. (A) Qualitative RT-PCR analysis. 25-50 ng total cellular RNA were reversetranscribed, and amplified by PCR for 32-34 cycles, as appropriate to maximize the differences between samples. One-sixth vol of each PCR reaction was size-fractionated on a $1 \%$ agarose gel, which was stained with ethidium bromide, and photographed. As a control, RNA was omitted from reverse transcription and PCR amplification. (B) Quantitative RT-PCR analysis. mRNA levels for IL-8 (•), IL-1 $\alpha$ $(O)$, and $\beta$-actin $(\boldsymbol{\nabla})$ were determined by quantitative RT-PCR using internal RNA standards, and are expressed as a ratio of the mRNA levels in C. trachomatis-infected cells to the levels in uninfected control cells. The absolute values of the mRNA levels for IL-8, IL- $1 \alpha$, and $\beta$-actin in control cells are shown in Table II.

ble III, all four chlamydial strains induced a $>20$-fold increase in IL-8 secretion by HeLa cells. Furthermore, the IL-8 response to $C$. trachomatis was not limited to HeLa cells, because $\mathrm{SiHa}$ cervical epithelial cells also secreted increased levels of IL-8 following infection. Because Chlamydia infection can cause proctitis, a colon epithelial cell line (HT-29) was tested. As shown in Table III, HT-29 cells also responded to $C$. trachomatis infection with increased IL-8 secretion, although the relative increase was lower than that observed for HeLa and $\mathrm{SiHa}$ cells. Thus, the cytokine response to chlamydial infection is a conserved feature among different chlamydiae, as well as the three epithelial cell lines tested.

Extracellular chlamydial LPS is not responsible for increased epithelial cytokine secretion following Chlamydia infection. Increased IL-8 secretion in response to chlamydial infection could be caused by the extracellular presence of Chlamydia, i.e., mediated by chlamydial cell wall components such as LPS, or by events associated with chlamydial invasion, or may require later events in the chlamydial life cycle involving bacterial protein synthesis and growth. To address the possibility that the extracellular presence of chlamydial LPS was responsible for the induction of IL-8, the colon epithelial cell line SW620 was used, which was previously shown to respond to relatively low levels of LPS with increased IL-8 secretion (33). Monolayers of SW620 cells that were infected with approximately 4 IFUs/cell of viable $C$. trachomatis L2, and incubated for $24 \mathrm{~h}$, showed a sixfold increase in IL-8 secretion $(2.26 \mathrm{ng}$ IL-8/ml after C. trachomatis infection, $0.36 \mathrm{ng}$ IL-8/ml in uninfected controls). In contrast, when the same inoculum was heat inactivated at $75^{\circ} \mathrm{C}$ for $10 \mathrm{~min}$ before coculture, a treatment which interferes with bacterial invasion but does not affect chlamydial LPS $(34,35)$, IL-8 secretion by SW620 monolayers did not increase $(0.36 \mathrm{ng}$ IL- $8 / \mathrm{ml}$ after addition of heat-treated

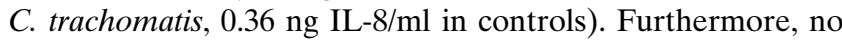
increase in IL-8 secretion by SW620 cells was observed after addition of up to an equivalent of 100 IFUs/cell of heat-inactivated $C$. trachomatis. As a positive control, LPS from E. coli O111 efficiently induced high levels of IL- 8 secretion by SW620 cells (14.41 ng IL-8/ml after stimulation with $100 \mathrm{ng} / \mathrm{ml}$ LPS for $24 \mathrm{~h}, 1.39 \mathrm{ng}$ IL-8/ml after stimulation with $1 \mathrm{ng} / \mathrm{ml}$ LPS, and $0.32 \mathrm{ng}$ IL- $8 / \mathrm{ml}$ in control cultures).

Bacterial protein synthesis is required for the induction of IL-8 by epithelial cells following chlamydial infection. To determine whether bacterial protein synthesis is required for the epithelial IL-8 response, epithelial monolayers were infected with Chlamydia for $2 \mathrm{~h}$ to allow invasion to occur, and treated with chloramphenicol to inhibit bacterial protein synthesis, growth, and replication (36). Chloramphenicol prevented the increase in IL-8 secretion from HeLa cells infected with $C$. trachomatis or $C$. psittaci (Fig. 4), and from HT-29 cells infected with $C$. trachomatis (C. trachomatis-infected $3.5 \pm 0.2 \mathrm{ng}$ IL-8/ $\mathrm{ml}$, C. trachomatis-infected + chloramphenicol $1.0 \pm 0.1 \mathrm{ng} / \mathrm{ml}$, controls $0.6 \pm 0.1 \mathrm{ng} / \mathrm{ml}$; supernatants were harvested $48 \mathrm{~h}$ after infection, data are mean \pm SD of triplicate cultures). In contrast, chloramphenicol had no effect on increased IL-8 secretion following IL-1 $\alpha$ stimulation of HeLa cells (data not shown).

We next asked whether differentiation of Chlamydia from RBs to EBs is important for IL-8 induction, because maximal IL-8 secretion was observed 2-3 d after infection, a time period that coincides with the condensation from $\mathrm{RBs}$ to $\mathrm{EBs}$, as well as maximal bacterial growth and metabolic activity. Penicillin inhibits $\mathrm{RB}$ division and $\mathrm{RB}$ to $\mathrm{EB}$ differentiation, but has no known effect on RB metabolism $(37,38)$. As shown in Fig. 4, addition of penicillin to freshly infected HeLa monolayers had little effect on the IL-8 response of these cells to $C$. psittaci and only slightly delayed the IL- 8 response following C. trachomatis infection. Similarly, the IL-8 response of HT-29 cells to $C$. trachomatis was only minimally affected by penicillin (C. trachomatis-infected $3.5 \pm 0.2 \mathrm{ng}$ IL-8/ml, C. trachomatis-infected + penicillin $2.5 \pm 0.2 \mathrm{ng} / \mathrm{ml}$, controls $0.6 \pm 0.1 \mathrm{ng} / \mathrm{ml}$; supernatants were harvested $48 \mathrm{~h}$ after infection, data are mean $\pm \mathrm{SD}$ of triplicate cultures). In summary, the epithelial IL-8 response to Chlamydia is independent of extracellular LPS, and is chloramphenicol-sensitive and penicillin-insensitive, suggesting that metabolism and growth of RBs, but not $\mathrm{RB}$ division and $\mathrm{RB}$ to $\mathrm{EB}$ differentiation, are required for this response, and that events subsequent to invasion of the host 
Table III. Different Chlamydia Strains Induce IL-8 Secretion by Human Cervical and Colon Epithelial Cells*

\begin{tabular}{|c|c|c|c|c|c|c|c|}
\hline \multirow[b]{2}{*}{ Cells } & \multirow[b]{2}{*}{ Chlamydia strains } & & \multirow{2}{*}{$\begin{array}{l}\text { Inoculum } \\
\text { (IFUs/well) }\end{array}$} & \multicolumn{2}{|c|}{ IL-8 secreted $(\mathrm{ng} / \mathrm{ml})^{\ddagger}$} & \multirow{2}{*}{$\begin{array}{c}\text { Ratio } \\
\text { Infected/Control }\end{array}$} & \multirow{2}{*}{$\begin{array}{l}\text { Number of } \\
\text { experiments }\end{array}$} \\
\hline & & & & Control & + Chlamydia & & \\
\hline \multirow[t]{4}{*}{$\mathrm{HeLa}$} & C. trachomatis & $\mathrm{L} 2 / 434 / \mathrm{Bu}$ & $1.0 \times 10^{5}$ & $0.2 \pm 0.1$ & $57.0 \pm 3.3^{\S}$ & 285 & 6 \\
\hline & & I/UW12/Ur & $2.0 \times 10^{5}$ & $0.3 \pm 0.1$ & $151.4 \pm 20.2^{\S}$ & 505 & 1 \\
\hline & & $\mathrm{D} / \mathrm{UW} 3 / \mathrm{Cx}$ & $6.5 \times 10^{4}$ & $0.6 \pm 0.2$ & $13.5 \pm 0.9^{\S}$ & 23 & 1 \\
\hline & C. psittaci & AP1 & $3.0 \times 10^{5}$ & $0.2 \pm 0.1$ & $35.6 \pm 2.1^{\S}$ & 178 & 5 \\
\hline $\mathrm{SiHa}$ & C. trachomatis & $\mathrm{L} 2 / 434 / \mathrm{Bu}$ & $3.6 \times 10^{4}$ & $<0.2$ & $51.4 \pm 12.0^{\S}$ & $>257$ & 2 \\
\hline HT-29 & C. trachomatis & $\mathrm{L} 2 / 434 / \mathrm{Bu}$ & $3.6 \times 10^{5}$ & $1.3 \pm 0.5$ & $14.6 \pm 1.6^{\S}$ & 11 & 4 \\
\hline
\end{tabular}

*Confluent monolayers of human cervical (HeLa and SiHa) and colon (HT-29) epithelial cells in 24-well plates were infected for $2 \mathrm{~h}$ with the indicated doses of Chlamydia, washed, and further incubated for 48-72 h. Medium was removed, fresh medium was added, and cultures were incubated for an additional $24 \mathrm{~h}$. Culture supernatants were collected, and IL-8 concentrations were determined by ELISA. HeLa cell cultures infected with $C$. trachomatis $\mathrm{D} / \mathrm{UW} 3 / \mathrm{Cx}$ were incubated for $96 \mathrm{~h}$ without a change in media before supernatants were collected. ${ }^{*}$ Results are means \pm SD of the values of triplicate cultures from representative experiments. The number of total experiments performed is given in the last column. ${ }^{8}$ Values are significantly different from the respective controls $(P \leq 0.01$, except SiHa for which $P \leq 0.05)$.

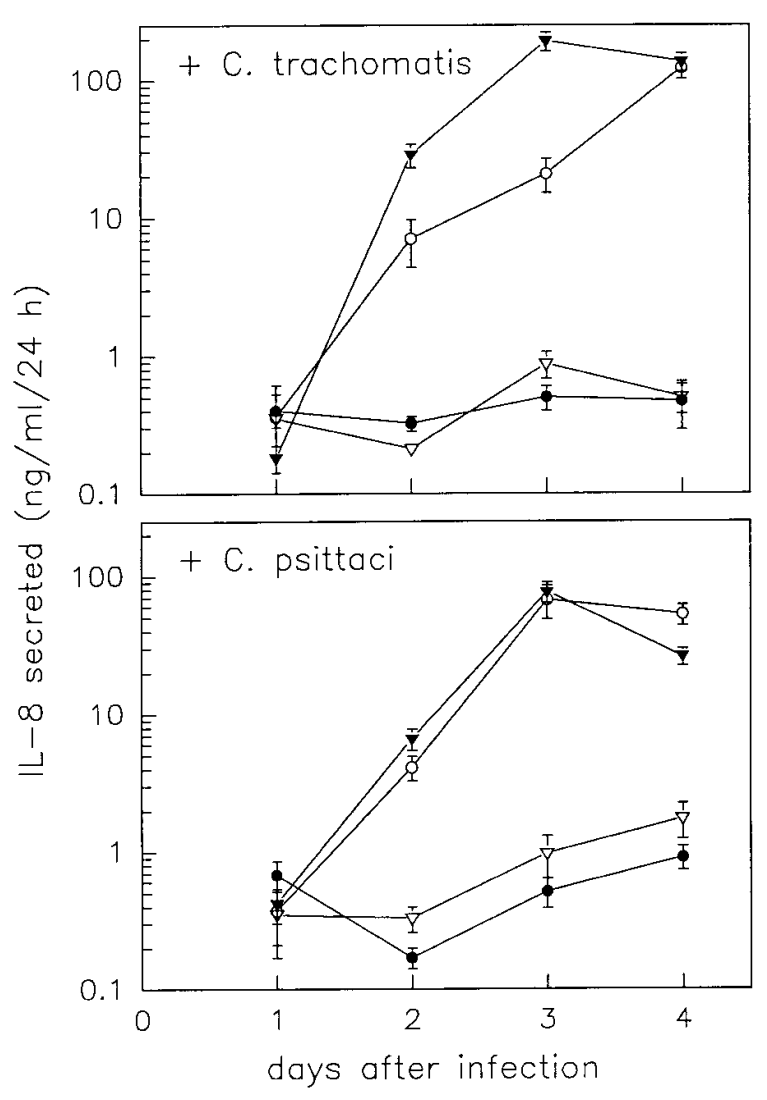

Figure 4. Effect of chloramphenicol and penicillin on Chlamydiainduced IL-8 secretion in HeLa cells. Monolayers of HeLa cells in 24well plates were infected for $2 \mathrm{~h}$ with approximately $1 \mathrm{IFU} / \mathrm{cell}$ of $C$. trachomatis, serovar L2 (top), or C. psittaci AP1 (bottom), washed, and fresh growth medium was added containing $68 \mu \mathrm{g} / \mathrm{ml}$ chloramphenicol $(\nabla)$, or $100 \mathrm{U} / \mathrm{ml}$ penicillin $\mathrm{G}(\bigcirc)$, or neither of these antibiotics $(\boldsymbol{\nabla})$. Mock-infected cultures $(\bullet)$ were used as controls. Cultures were incubated for $4 \mathrm{~d}$, during which supernatants were collected and replaced every $24 \mathrm{~h}$ with fresh media containing the appropriate antibiotics. IL- 8 concentrations in the 24 -h supernatants were determined by ELISA. Data represent means \pm SD of the results of triplicate cultures from one representative out of a total of three (C. trachomatis) or two (C. psittaci) experiments. Values of untreated infected cultures were significantly increased compared with uninfected controls at 2 , cells are essential for eliciting increased epithelial IL-8 expression and secretion.

Increased cytokine secretion by Chlamydia-infected epithelial cell lines is partly mediated by the cellular release of $I L-1 \alpha$. Chlamydial growth causes lysis of the host cells 2-5 d after infection, and previous studies have shown that HeLa and other epithelial cells contain preformed bioactive IL- $1 \alpha$ that can be released upon cell lysis (39). Because IL-1 $\alpha$ is a potent stimulus for IL-8 secretion, the possibility was tested that the observed induction of IL-8 and other cytokines after chlamydial infection is mediated by the release of IL-1 $\alpha$. HeLa, SiHa, or HT-29 cells were infected with 1 IFU/cell $C$. trachomatis L2 and cultured for up to $4 \mathrm{~d}$. During this time, the supernatants were replaced every $24 \mathrm{~h}$ with fresh media containing antiIL- $1 \alpha$ or control antibodies. As shown in Fig. 5, addition of anti-IL- $1 \alpha$ inhibited up to $85 \%$ of the increase in IL- 8 secretion by $\mathrm{HeLa}$ and $\mathrm{SiHa}$ cells following chlamydial infection compared with Chlamydia-infected control cultures containing no added antibodies, or antibodies of irrelevant specificity. The anti-IL- $1 \alpha$-mediated inhibition of IL- 8 secretion was observed within $24 \mathrm{~h}$ after infection, and the relative magnitude of the inhibition was similar throughout the 4-d period of the experiment (Fig. 5, and data not shown). In control experiments, an identical concentration of anti-IL-1 $\alpha$ to that used in the experiments with Chlamydia-infected cultures completely inhibited $(>99 \%)$ the increase in IL-8 secretion by HeLa and $\mathrm{SiHa}$ cells following stimulation with $1 \mathrm{ng} / \mathrm{ml}$ IL- $1 \alpha$. Furthermore, addition of anti-IL- $1 \alpha$ inhibited $>95 \%$ of the increase in the secretion of GRO $\alpha$, GM-CSF, and IL- 6 following infection of HeLa cells with C. trachomatis (data not shown), indicating that the release of IL- $1 \alpha$ from infected cells played an important role in the Chlamydia-induced induction of all of the cytokines tested.

3 , and $4 \mathrm{~d}$ after infection for both chlamydial strains $(P \leq 0.01)$. No significant increase was found between chloramphenicol-treated infected cultures and uninfected controls at any time point $(P>0.05)$. The efficacy of the antibiotic treatments was confirmed by microscopic examination of monolayers stained with antibodies against chlamydial LPS. 


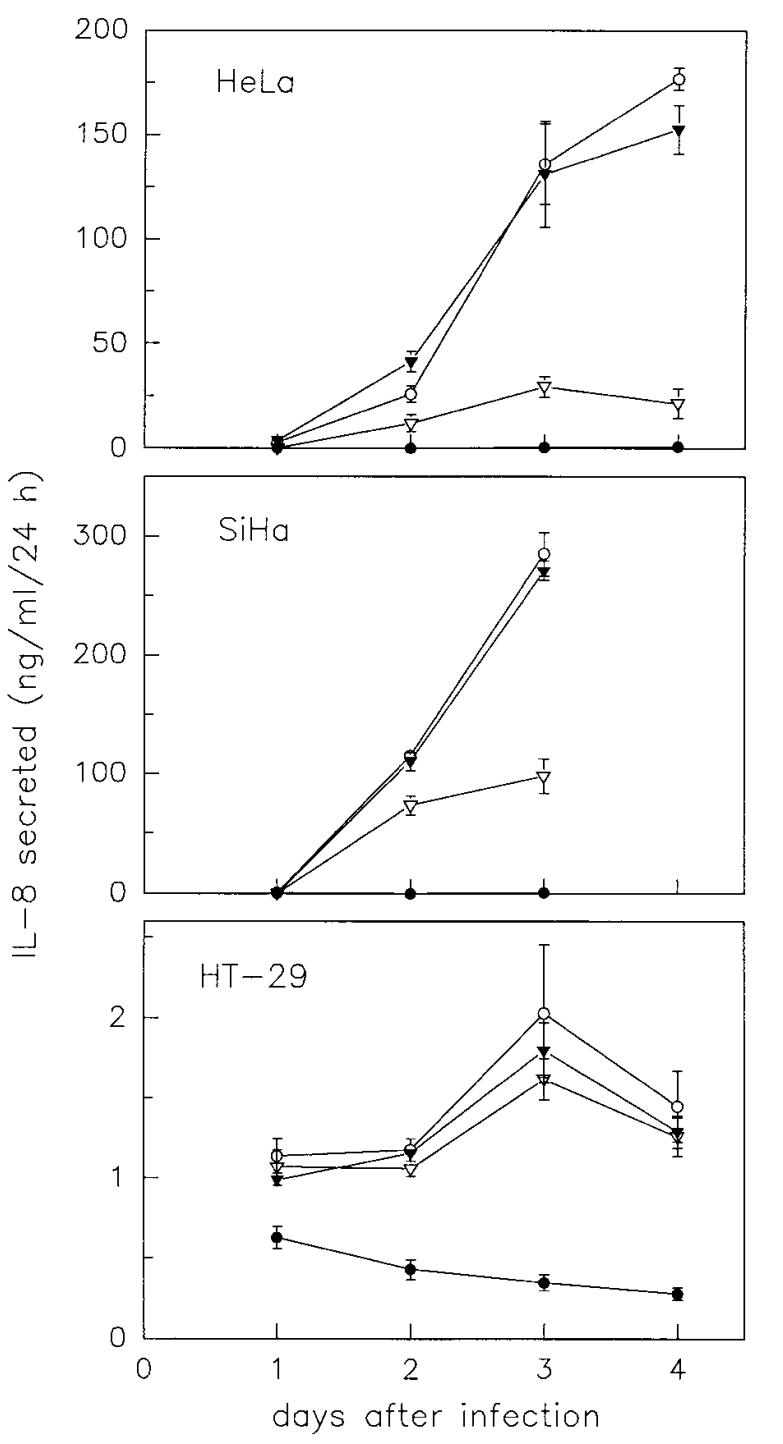

Figure 5. Role of IL- $1 \alpha$ in mediating increased IL- 8 secretion following C. trachomatis infection. Monolayers of the indicated cell lines in 24-well plates were infected for $2 \mathrm{~h}$ with approximately $1 \mathrm{IFU} / \mathrm{cell}$ of C. trachomatis (serovar L2), washed, and further incubated without added antibodies $(\boldsymbol{\nabla})$, or in the presence of $20 \mu \mathrm{g} / \mathrm{ml}$ goat anti-human IL-1 $\alpha(\nabla)$, or $20 \mu \mathrm{g} / \mathrm{ml}$ normal goat IgG as antibody controls $(\bigcirc)$. Mock infected cultures $(\bullet)$ were used as negative controls. Cultures were incubated for 3-4 d, during which supernatants were collected and replaced every $24 \mathrm{~h}$ with new media with or without the appropriate antibodies. IL-8 concentrations in the 24 -h supernatants were determined by ELISA. Data represent means \pm SD of the results of triplicate cultures. Values of untreated infected cultures were significantly increased compared with uninfected controls at 2, 3, and $4 \mathrm{~d}$ after infection for all three cell lines $(P \leq 0.02)$. Values from antiIL- $1 \alpha$-treated infected cultures were significantly different from control Ig-treated infected cultures at days 2, 3, and 4 for HeLa and days 2 and 3 for SiHa cells $(P \leq 0.02)$, whereas no significant difference was found between anti-IL- $1 \alpha$-treated and control Ig- treated infected HT-29 cultures at any time point $(P>0.05)$. Two additional experiments with HeLa and HT-29 cells confirmed these results. Thus, HeLa cell cultures infected with C. psittaci for $72 \mathrm{~h}$ contained $35.6 \mathrm{ng} \mathrm{IL-}-8 / \mathrm{ml}$, while uninfected controls had $0.2 \mathrm{ng} / \mathrm{ml}$. Addition of anti-IL- $1 \alpha$ and control Ig to the $C$. psittaci-infected HeLa cultures resulted in 20.6 and $36.2 \mathrm{ng} \mathrm{IL-} 8 / \mathrm{ml}$, respectively, indicating a $42 \%$ inhibition of IL- 8 secretion by anti-IL-1 $\alpha$. In HT- 29 cells, $C$. trachomatis infection increased IL-8 secretion to $2.57 \mathrm{ng} / \mathrm{ml} 48 \mathrm{~h}$ after infection
In contrast to the findings in $\mathrm{HeLa}$ and $\mathrm{SiHa}$ cells, addition of anti-IL-1 $\alpha$ did not inhibit increased secretion of IL-8 (Fig. 5) and GRO $\alpha$ (data not shown) by Chlamydia-infected HT-29 cells. Nonetheless, IL- $1 \alpha$ stimulation of HT-29 cells increased IL-8 secretion 500-fold, indicating that these cells are IL-1 $\alpha$ responsive, and addition of anti-IL- $1 \alpha$ antibodies completely blocked this response (data not shown). These findings are consistent with previous observations that HT-29 cells neither contain IL- $1 \alpha$ (39) nor express IL- $1 \alpha$ mRNA, as determined by RT-PCR (28). The lack of IL-1 $\alpha$ expression in HT-29 cells may explain why the relative increase in IL- 8 secretion by HT-29 cells infected with optimal doses of $C$. trachomatis was lower than that of HeLa or SiHa cells, because the amplifying effect of IL- $1 \alpha$ release on IL- 8 secretion is absent in HT-29 cells. Of note, all three cell lines displayed a similar susceptibility to Chlamydia infection, as determined by the ability of identical Chlamydia inocula to form inclusions in these cells (data not shown). Taken together, the data indicate that the increase in epithelial IL-8 secretion following chlamydial infection is mediated by at least two mechanisms, one involving IL- $1 \alpha$ release and one independent of IL- $1 \alpha$.

Increased IL-8 secretion by primary endocervical epithelial cells in response to $C$. trachomatis infection. To verify that the IL-8 response to $C$. trachomatis was not limited to transformed epithelial cell lines, primary human epithelial cell cultures were established from normal endocervix, and infected with $C$. trachomatis. As shown in Table IV, IL-8 secretion by primary endocervical epithelial cells increased 1.5- to 3.4-fold after $C$. trachomatis infection. In experiments which showed a relatively lower increase in IL- 8 secretion after infection, the levels of IL- 8 secretion by control cells tended to be greater than those in control cells in experiments in which greater IL-8 induction was observed (compare experiments 1 and 2, subject 3 in Table IV, and data not shown). Thus, maximal IL-8 levels after $C$. trachomatis infection were similar in most experiments, while IL-8 secretion in control cultures was more variable between experiments. Stimulation of primary endocervical epithelial cell cultures with a combination of the agonists IL- $1 \alpha$ and TNF $\alpha$ increased IL- 8 secretion by 1.7 - to 10.9 -fold (Table IV), suggesting that IL-8 secretion by control cultures was relatively close to maximal in some cases. The findings in primary endocervical epithelial cells are consistent with the observations in the cervical epithelial cell lines, although the relative magnitude of the IL- 8 response to $C$. trachomatis was lower in the primary cells due to a higher level of background secretion in the control cultures. The lower relative magnitude of the IL-8 response in infected primary epithelial cell monolayers may also be related to the finding that only $10-30 \%$ of cells contained chlamydial inclusions, whereas in HeLa cell monolayers infected with $C$. trachomatis under comparable conditions $>90 \%$ of cells had chlamydial inclusions.

Primary endocervical epithelial cells contain bioactive $I L-1 \alpha$ that is released following $C$. trachomatis infection. The studies with transformed cervical epithelial cell lines indicated that release of IL- $1 \alpha$ is an important mechanism by which the IL- 8 response of these cells is amplified following C. trachomatis in-

compared with $0.62 \mathrm{ng} / \mathrm{ml}$ in uninfected controls. Addition of antiIL-1 $\alpha$ and control Ig had no significant effect on the increase in IL-8 secretion (2.33 and $3.34 \mathrm{ng} / \mathrm{ml}$, respectively) after infection. 


\begin{tabular}{|c|c|c|c|c|c|c|c|}
\hline \multirow[b]{3}{*}{ Cells } & \multirow[b]{3}{*}{ Subject } & \multirow[b]{3}{*}{ Exp. } & \multicolumn{5}{|c|}{ IL-8 secreted } \\
\hline & & & \multirow{2}{*}{$\frac{\text { Control }}{\mathrm{ng} / \mathrm{ml}}$} & \multicolumn{2}{|c|}{+ C. trachomatis $\mathrm{L} 2^{\ddagger}$} & \multicolumn{2}{|c|}{$+\mathrm{IL}-1 \alpha+\mathrm{TNF} \alpha$} \\
\hline & & & & $\mathrm{ng} / \mathrm{ml}$ & $\begin{array}{c}\text { Ratio } \\
\text { Infected/Control }\end{array}$ & $\mathrm{ng} / \mathrm{ml}$ & $\begin{array}{c}\text { Ratio } \\
\text { Stimulated/Control }\end{array}$ \\
\hline \multirow[t]{4}{*}{ Primary endocervical epithelial cells } & 1 & 1 & 37.5 & 72.3 & 1.9 & 62.5 & 1.7 \\
\hline & 2 & 1 & 22.1 & 65.5 & 3.0 & 239.8 & 10.9 \\
\hline & 3 & 1 & 29.9 & 43.6 & 1.5 & $223.8^{\S}$ & 7.5 \\
\hline & & 2 & 11.9 & 40.3 & 3.4 & 21.8 & 1.8 \\
\hline HeLa cervical epithelial cells $\|$ & & & 0.8 & 19.2 & 24.0 & $8.0^{\S}$ & 10.0 \\
\hline
\end{tabular}

* Primary endocervical epithelial cell cultures were established as described in Methods. Subconfluent monolayers in 24-well plates were infected for $2 \mathrm{~h}$ with $C$. trachomatis L2, washed, and further incubated for $3 \mathrm{~d}$. Parallel cultures were stimulated with $20 \mathrm{ng} / \mathrm{ml}$ each of IL- $1 \alpha$ and TNF $\alpha$. IL-8 concentrations in the supernatants were determined by ELISA. For subject 3, two different subcultures of the original primary cultures were used for two separate experiments. Cultures contained approximately $5-9 \times 10^{4}$ cells/well. ${ }^{\ddagger}$ Monolayers were infected with $2 \times 10^{5}$ IFUs/well. Infectivity was confirmed by indirect immunofluorescence with an antibody against chlamydial major outer membrane protein. ${ }^{\S}$ Cells were stimulated with IL-1 $\alpha$ only. ${ }^{\mathrm{H}} \mathrm{HeLa}$ cells were adapted to serum-free conditions before infection, and infection experiments were performed under identical conditions to those used for the primary cell cultures.

fection. Therefore, we asked whether primary endocervical epithelial cells also contain bioactive IL-1 $\alpha$. As shown in Table $\mathrm{V}$, lysates from primary endocervical epithelial cells induced IL-8 secretion by HeLa cells, and this activity was completely blocked by addition of anti-IL-1 $\alpha$. Furthermore, supernatants from $C$. trachomatis-infected primary endocervical epithelial cells increased IL- 8 secretion by HeLa cells, and the increase was blocked by anti-IL-1 $\alpha$ (Table V), indicating that bioactive IL-1 $\alpha$ was released from primary endocervical epithelial cells during infection with $C$. trachomatis. Supernatants from uninfected primary control cultures also increased IL-8 secretion by HeLa cells, although to a much lesser extent than supernatants from infected cells. The IL-8-inducing activity in control supernatants also was blocked by anti-IL-1 $\alpha$, indicating that the relatively high level of IL-8 secretion in primary control cultures (Table IV) may be related to the spontaneous release of IL- $1 \alpha$.

\section{Discussion}

Chlamydial infections are characterized by intense and persistent local inflammation that is exacerbated upon reinfection, ultimately leading to tissue damage and scarring. The mechanisms which elicit this response are unknown, but an understanding of this process is central to the prevention and mitigation of disease. The findings presented here suggest a novel concept for chlamydial pathogenesis wherein the acute host response to Chlamydia in the genital tract, and at other mucosal surfaces, is primarily initiated and sustained by epithelial cells, the first and main targets of chlamydial infection. As shown herein, Chlamydia-infected epithelial cells expressed and secreted increased levels of the chemokines IL-8 and GRO $\alpha$, as well as the cytokines GM-CSF, IL- $1 \alpha$, and IL-6. Several of these cytokines are potent chemoattractants and activators for neutrophils, monocytes, and T lymphocytes (40), while others have pleiotropic effects on cell functions associated with acute inflammation, including the induction of adhesion molecules on endothelial cells, the secretion of additional proinflammatory cytokines by macrophages and other cells, and the induc- tion of acute phase proteins in epithelial cells and macrophages $(41,42)$. Thus, the array of cytokines produced by epithelial cells after chlamydial infection is consistent with the nature of the host inflammatory response in vivo.

In addition to the epithelial proinflammatory cytokine response, other mechanisms may be involved in the innate immune response to Chlamydia. For example, chlamydial EBs are chemotactic for neutrophils which, in part, is due to activation of the neutrophil chemoattractant C5a (43). In addition, chlamydial LPS can stimulate proinflammatory cytokine secretion by macrophages (44). However, chlamydial LPS is much less potent than LPS of other gramnegative bacteria (44, 45), macrophages typically are not a major target of Chlamydia infection, and epithelial cells of the genital and gastrointestinal tracts often are poorly responsive to LPS $(26,33)$. The conclusion that chlamydial LPS is not important in eliciting the production of proinflammatory cytokines from epithelial cells is further supported by the present finding that an epithelial cell line, SW620, known to be LPS-sensitive (33) failed to respond to high doses of heat-inactivated Chlamydia.

The time course of cytokine induction following chlamydial infection was considerably delayed compared to that found previously for infection of epithelial cells with other invasive bacteria (26), suggesting that different mechanisms are involved. No increase in cytokine secretion was detected during the first $8 \mathrm{~h}$ after chlamydial infection, induction of maximal secretion required at least $48 \mathrm{~h}$, and high-level secretion persisted throughout the bacterial growth cycle (up to $4 \mathrm{~d}$ ). In contrast, cytokine secretion following infection with Salmonella increases within 90 min after infection, reaches maximal levels at $3 \mathrm{~h}$, and decreases rapidly thereafter (26). Consistent with the rapid cytokine response to Salmonella and other invasive bacteria, which use different invasion strategies, host cell responses closely associated with bacterial invasion appear to be crucial for the epithelial cytokine response to these bacteria (26). The relatively delayed induction of cytokine secretion, and the absence of increased cytokine secretion by Chlamydiainfected cells treated with chloramphenicol, indicate that chlamydial invasion alone is not responsible for the epithelial 
Table V. Primary Endocervical Epithelial Cells Contain Bioactive IL-1 $\alpha$ That Is Released after C. trachomatis Infection*

\begin{tabular}{|c|c|c|c|c|c|c|}
\hline \multirow[b]{2}{*}{ Exp. } & \multirow[b]{2}{*}{ Stimulators added } & \multirow[b]{2}{*}{ Subject $^{\S}$} & \multicolumn{4}{|c|}{ IL-8 secreted (pg/ml) } \\
\hline & & & No inhibitor added & + Anti-IL-1 $1 \alpha^{\|}$ & + Anti-TNF $\alpha{ }^{\|}$ & + Control Ig ${ }^{\| \mathbb{I}}$ \\
\hline \multirow[t]{6}{*}{1} & Epithelial cell lysate & 3 & $4,016 \pm 149$ & $42 \pm 9 * *$ & $3,962 \pm 481$ & $4,020 \pm 76$ \\
\hline & Epithelial cell lysate & 4 & $1,375 \pm 124$ & $31 \pm 4 * *$ & $1,351 \pm 113$ & $1,593 \pm 96$ \\
\hline & SN, Chlamydia-infected & $3(\exp .2)$ & $298 \pm 82$ & $30 \pm 5 * *$ & $237 \pm 23$ & $247 \pm 20$ \\
\hline & SN, Control & 3 (exp. 2) & $62 \pm 2$ & $20 \pm 4 * *$ & $50 \pm 6$ & $73 \pm 17$ \\
\hline & IL- $1 \alpha$ & & $3,588 \pm 257$ & $25 \pm 6^{* *}$ & $3,581 \pm 340$ & $4,276 \pm 746$ \\
\hline & None & & $42 \pm 15$ & $36 \pm 2$ & $39 \pm 8$ & $42 \pm 12$ \\
\hline \multirow[t]{4}{*}{2} & SN, Chlamydia-infected & 2 & $748 \pm 22$ & $173 \pm 16^{* *}$ & $671 \pm 80$ & $601 \pm 67$ \\
\hline & SN, Control & 2 & $332 \pm 8$ & $149 \pm 13 * *$ & $285 \pm 31$ & $245 \pm 37$ \\
\hline & $\mathrm{TNF} \alpha$ & & $693 \pm 38$ & $626 \pm 9$ & $178 \pm 14$ & $666 \pm 20$ \\
\hline & None & & $198 \pm 22$ & $150 \pm 9$ & $172 \pm 19$ & $194 \pm 14$ \\
\hline
\end{tabular}

*Confluent HeLa cell monolayers in 96-well plates were stimulated for $1 \mathrm{~h}$ with cell lysates or supernatants from primary endocervical epithelial cell cultures $(50 \mu \mathrm{l} /$ well). Cultures were washed three times, and further incubated for $4 \mathrm{~h}$ with fresh medium $(75 \mu \mathrm{l} /$ well). IL- 8 concentrations in the supernatants were determined by ELISA. Results are means \pm SD of the results of triplicate cultures. Preliminary experiments had shown that a $1 \mathrm{~h}$ prestimulation period with IL-1 $\alpha$ is sufficient to obtain maximal IL-8 secretion in the subsequent $4 \mathrm{~h}$ culture period whether or not IL- $1 \alpha$ was present during the 4-h period. ${ }^{*}$ To obtain cell lysates from primary endocervical epithelial cells, cultures were established as described in Methods, and subconfluent monolayers in 24-well plates were scraped off into $1 \mathrm{ml}$ medium, and sonicated for $5 \mathrm{~s}$ on ice. Lysates were used at $25 \%$ final concentration. Supernatants (SN) from C. trachomatis-infected and uninfected control cultures were obtained as described in the legend to Table IV, and were used at $25 \%$ final concentration. IL- $1 \alpha$ was used at $1 \mathrm{ng} / \mathrm{ml}$, and TNF $\alpha$ was used at $2 \mathrm{ng} / \mathrm{ml}$. ${ }^{\S}$ Subject and experiment numbers correspond to those in Table IV. "Goat antibodies against human IL- $1 \alpha$ or TNF $\alpha$, or normal goat IgG as a control, were added to supernatants or cell lysates at $25 \mu \mathrm{g} / \mathrm{ml}$. The mixtures were incubated for $30 \mathrm{~min}$ at room temperature, and used to stimulate HeLa cell monolayers. "None of the control Ig values is significantly different from the respective no inhibitor controls $(P>0.05)$. **Values are significantly different from the respective no inhibitor controls $(P \leq 0.05)$.

cytokine response, although invasion is required for the development of subsequent stages of the chlamydial life cycle.

Chlamydial invasion of host cells seems to differ fundamentally from the invasion strategies used by other bacterial pathogens in that it appears to be silent and does not induce cellular signaling pathways that lead to a rapid increase in the expression of proinflammatory cytokines. The silent invasion by Chlamydia was not due to an inhibitory effect of Chlamydia, because IL-1 or TNF $\alpha$ stimulation of Chlamydia-infected HeLa epithelial cells increased IL-8 secretion to levels comparable with those in agonist-stimulated uninfected control cells (data not shown). The lack of cytokine induction during chlamydial invasion may not be related to a particular invasion strategy, but to the size of the invading organism, which, at 300 $\mathrm{nm}$ diameter, is considerably smaller than that of the bacteria tested in previous studies $(26-28,46)$.

IL-1 $\alpha$ released from Chlamydia-infected cells was an important agonist for proinflammatory cytokine secretion by the cervical epithelial cell lines. A similar role for IL-1 $\alpha$ has been reported in the induction of the proinflammatory cytokine response of cultured epithelial and stromal cells to the cytolytic protozoan parasite Entamoeba histolytica (39), and for the endothelial cell response to Rickettsia conorii (47). Whereas E. histolytica causes cell lysis of infected monolayers and release of preformed cellular IL-1 $\alpha$ within $2-4 \mathrm{~h}$ after infection, that is paralleled by the increased secretion of proinflammatory cytokines (39), cell lysis following chlamydial infection is relatively slow and requires several days to occur. This suggests that, in the case of Chlamydia infection, the release of IL- $1 \alpha$ through cell lysis is important for increased cytokine production mainly at the later stages of the chlamydial infection. However, inhibition of IL- $1 \alpha$ activity blocked IL- 8 secretion to a similar extent throughout the course of the chlamydial infec- tion cycle, indicating that IL- $1 \alpha$ release may be important for inducing IL-8 secretion as early as $24 \mathrm{~h}$ after Chlamydia infection. It is possible that mature IL-1 $\alpha$ is secreted by viable cells early after infection in the absence of cell lysis. Alternatively, some Chlamydia- infected cells may lyse more rapidly than others and release cytoplasmic IL-1 $\alpha$ precursor relatively early after infection. In either case, IL- $1 \alpha$ is bioactive because the cytoplasmic precursor and the secreted form of IL-1 $\alpha$ have comparable specific activities (48).

IL-1 $\alpha$ was not the only stimulus responsible for increased IL-8 secretion in response to chlamydial infection, because IL-8 secretion also was seen in the absence of IL- $1 \alpha$ release. Thus, HT-29 colon epithelial cells secreted IL-8 following infection, but these cells neither express IL- $1 \alpha$ mRNA nor contain IL- $1 \alpha$ $(28,39)$. Together with the inability of anti-IL-1 $\alpha$ to completely block IL-8 production in Chlamydia-infected HeLa or SiHa cells, this suggests that infected epithelial cells secrete IL-8 in direct response to the intracellular presence of Chlamydia. The cellular signaling pathways underlying this response are not known, but some second messenger systems in host cells appear to be directly activated by chlamydial infection, because specific host cell proteins become phosphorylated rapidly after chlamydial infection (49). Alternatively, the production and accumulation of bacterial metabolites may be important for inducing epithelial cytokine synthesis, a possibility that would be consistent with the requirement for chlamydial metabolism for the induction of the epithelial cytokine response.

Primary endocervical epithelial cells, like the cervical epithelial cell lines, responded to chlamydial infection with increased IL-8 secretion and the release of bioactive IL- $1 \alpha$. However, the relative magnitude of the increase in IL- 8 secretion in response to $C$. trachomatis infection was lower in the primary cells than in the transformed cell lines, reflecting a rel- 
atively high level of IL-8 secretion in the control cultures. It appears unlikely that endocervical epithelial cells in vivo constitutively secrete high levels of IL-8, because the normal endocervical mucosa does not contain large numbers of neutrophils. Constitutive IL- 8 secretion by cultured control endocervical epithelial cells may simply reflect the culture conditions, as suggested by the finding that supernatants of control cultures contained bioactive IL- $1 \alpha$. Nevertheless, increased release of IL- $1 \alpha$ from primary endocervical epithelial cells after Chlamydia infection could induce epithelial cytokine production and the production of proinflammatory cytokines by cells, such as macrophages and fibroblasts, in the underlying mucosa.

The increased production of proinflammatory cytokines by epithelial cells in response to chlamydial infection likely is important for recruiting inflammatory cells to the site of infection. The resulting inflammation presumably would have both protective and deleterious effects, because the inflammatory response can help to resolve the infection as well as contribute to fibrosis and tissue scarring (50). An important, yet unresolved, question is whether mitigation of the epithelial cytokine response, and the ensuing acute inflammation, would decrease the damaging sequelae of chlamydial infection or, alternatively, promote the spread of infection and increase tissue damage in the host. The epithelial cytokine response to Chlamydia infection reported herein offers a new perspective in understanding chlamydial pathogenesis, because it can explain acute inflammation, as well as the inflammation in repeated infections. A corollary of these findings is that vaccination directed towards developing serum antibodies and antigen-specific T lymphocytes against Chlamydia may not prevent acute inflammation, because the epithelial cytokine response would not be diminished unless the vaccine prevented initial epithelial cell infection. This may, at least in part, explain the outcome of chlamydial vaccination trials, in which vaccination did not prevent mucosal inflammation and, in some cases, was associated with more severe disease following chlamydial reinfection (16).

\section{Acknowledgments}

We thank Jennifer R. Smith for expert technical help, and Suk-Kyun Yang for providing plasmids used for the quantitative RT-PCR analysis.

This work was supported by National Institutes of Health grants EY-07757, AI-32943, DK-35108, AI-39042, and AI-38515. S.J. Rasmussen is a recipient of a postdoctoral fellowship from the Fight For Sight Research Division of Prevent Blindness America. L. Eckmann is a recipient of a Career Development Award of the Crohn's and Colitis Foundation of America.

\section{References}

1. West, S.K., P. Rapoza, B. Munoz, S. Katala, and H.R. Taylor. 1991. Epidemiology of ocular chlamydial infection in a trachoma-hyperendemic area. $J$. Infect. Dis. 163:752-756.

2. Laga, M., A. Manoka, M. Kivuvu, B. Malele, M. Tuliza, N. Nzila, J. Goeman, V. Batter, and M. Alary. 1993. Non-ulcerative sexually transmitted diseases as risk factors for HIV-1 transmission in women: results from a cohort study. AIDS (Phila.). 7:95-102.

3. Ho, J.L., S. He, A. Hu, J. Geng, F.G. Basile, M.G. Almeida, A.Y. Saito, J. Laurence, and W.D. Johnson. 1995. Neutrophils from human immunodeficiency virus (HIV)-seronegative donors induce HIV replication from HIVinfected patients' mononuclear cells and cell lines: an in vitro model of HIV transmission facilitated by Chlamydia trachomatis. J. Exp. Med. 181:1493-1505.

4. Storz, J. 1988. Overview of animal diseases induced by chlamydial infections. In Microbiology of Chlamydia. A.L. Barron, editor. CRC Press, Boca Ra- ton, FL. 167-192.

5. Moulder, J.W. 1991. Interaction of Chlamydiae and host cells in vitro. Microbiol. Rev. 55:143-190.

6. Eissenberg, L.G., and P.B. Wyrick. 1981. Inhibition of phagolysosome fusion is localized to Chlamydia psittaci-laden vacuoles. Infect. Immun. 32:889-896.

7. Kuo, C.-C. 1988. Host response. In Microbiology of Chlamydia. A.L. Barron, editor. CRC Press, Boca Raton. 193-208.

8. Rank, R.G., L.S. Soderberg, and A.L. Barron. 1985. Chronic chlamydial genital infection in congenitally athymic nude mice. Infect. Immun. 48:847-849.

9. Whittum-Hudson, J.A., T.P. O'Brien, and R.A. Prendergast. 1995. Murine model of ocular infection by a human biovar of Chlamydia trachomatis. Invest. Ophthalmol. Visual Sci. 36:1976-1987.

10. Monnickendam, M.A., S. Darougar, J.D. Treharne, and A.M. Tilbury. 1980. Development of chronic conjunctivitis with scarring and pannus, resembling trachoma, in guinea-pigs. Br. J. Ophthalmol. 64:284-290.

11. Brunham, R.C., C. Kuo, and W.J. Chen. 1985. Systemic Chlamydia trachomatis infection in mice: a comparison of lymphogranuloma venereum and trachoma biovars. Infect. Immun. 48:78-82.

12. Yong, E.C., E.Y. Chi, W.J. Chen, and C.C. Kuo. 1986. Degradation of Chlamydia trachomatis in human polymorphonuclear leukocytes: an ultrastructural study of peroxidase-positive phagolysosomes. Infect. Immun. 53:427-431.

13. Yong, E.C., S.J. Klebanoff, and C.C. Kuo. 1982. Toxic effect of human polymorphonuclear leukocytes on Chlamydia trachomatis. Infect. Immun. 37: 422-426.

14. Williams, D.M., J. Schachter, D.J. Drutz, and C.V. Sumaya. 1981. Pneumonia due to Chlamydia trachomatis in the immunocompromised (nude) mouse. J. Infect. Dis. 143:238-241.

15. Ramsey, K.H., L.S. Soderberg, and R.G. Rank. 1988. Resolution of chlamydial genital infection in B-cell-deficient mice and immunity to reinfection. Infect. Immun. 56:1320-1325.

16. Grayston, J.T., S.P. Wang, L.J. Yeh, and C.C. Kuo. 1985. Importance of reinfection in the pathogenesis of trachoma. Rev. Infect. Dis. 7:717-725.

17. Morrison, R.P., K. Lyng, and H.D. Caldwell. 1989. Chlamydial disease pathogenesis. Ocular hypersensitivity elicited by a genus-specific $57-\mathrm{kD}$ protein. J. Exp. Med. 169:663-675.

18. Rank, R.G., C. Dascher, A.K. Bowlin, and P.M. Bovoil. 1995. Systemic immunization with Hsp60 alters the development of chlamydial ocular disease. Invest. Ophthalmol. Visual Sci. 36:1344-1351.

19. Rasmussen, S.J., P. Timms, P.R. Beatty, and R.S. Stephens. 1996. Cytotoxic-T-lymphocyte-mediated cytolysis of $\mathrm{L}$ cells persistently infected with Chlamydia spp. Infect. Immun. 64:1944-1949.

20. Eckmann, L., M.F. Kagnoff, and J. Fierer. 1995. Intestinal epithelial cells as watchdogs for the natural immune system. Trends Microbiol. 3:118-120.

21. DiMango, E., H.J. Zar, R. Bryan, and A. Prince. 1995. Diverse Pseudomonas aeruginosa gene products stimulate respiratory epithelial cells to produce interleukin-8. J. Clin. Invest. 96:2204-2210.

22. Inoue, H., P.P. Massion, I.F. Ueki, K.M. Grattan, M. Hara, A.F. Dohrman, B. Chan, J.A. Lausier, J.A. Golden, and J.A. Nadel. 1994. Pseudomonas stimulates interleukin-8 mRNA expression selectively in airway epithelium, in gland ducts, and in recruited neutrophils. Am. J. Respir. Cell Mol. Biol. 11:651-663.

23. Agace, W.W., S.R. Hedges, M. Ceska, and C. Svanborg. 1993. Interleukin- 8 and the neutrophil response to mucosal gram-negative infection. J. Clin. Invest. 92:780-785.

24. Crowe, S.E., L. Alvarez, M. Dytoc, R.H. Hunt, M. Muller, P. Sherman, J. Patel, Y. Jin, and P.B. Ernst. 1995. Expression of interleukin 8 and CD54 by human gastric epithelium after Helicobacter pylori infection in vitro. Gastroenterology. 108:65-74.

25. Sharma, S.A., M.K. Tummuru, G.G. Miller, and M.J. Blaser. 1995. Interleukin-8 response of gastric epithelial cell lines to Helicobacter pylori stimulation in vitro. Infect. Immun. 63:1681-1687.

26. Eckmann, L., M.F. Kagnoff, and J. Fierer. 1993. Epithelial cells secrete the chemokine interleukin-8 in response to bacterial entry. Infect. Immun. 61: 4569-4574.

27. McCormick, B.A., S.P. Colgan, C. Delp-Archer, S.I. Miller, and J.L. Madara. 1993. Salmonella typhimurium attachment to human intestinal epithelial monolayers: Transcellular signalling to subepithelial neutrophils. J. Cell Biol. 123:895-907.

28. Jung, H.C., L. Eckmann, S.K. Yang, A. Panja, J. Fierer, E. MorzyckaWroblewska, and M.F. Kagnoff. 1995. A distinct array of proinflammatory cytokines is expressed in human colon epithelial cells in response to bacterial invasion. J. Clin. Invest. 95:55-65.

29. Mahida, Y.R., S. Makh, S. Hyde, T. Gray, and S.P. Borriello. 1996. Effects of Clostridium difficile toxin A on human intestinal epithelial cells: induction of interleukin 8 production and apoptosis after cell detachment. Gut. 38: 337-347.

30. McGee, D.W., C.O. Elson, and J.R. McGhee. 1993. Enhancing effect of cholera toxin on interleukin-6 secretion by IEC-6 intestinal epithelial cells: mode of action and augmenting effect of inflammatory cytokines. Infect. Immun. 61:4637-4644.

31. Clyne, J.M., J.A. Running, M. Stempien, R.S. Stephens, H. AkhavanTafti, A.P. Schaap, and M.S. Urdea. 1989. A rapid chemiluminescent DNA hybridization assay for the detection of Chlamydia trachomatis. J. Biolumin. 
Chemilumin. 4:357-366.

32. McCartney-Francis, N.L., and S.M. Wahl. 1994. Transforming growth factor $\beta$ : A matter of life and death. J. Leukocyte Biol. 55:401-409.

33. Eckmann, L., H.C. Jung, C. Schurer-Maly, A. Panja, E. MorzyckaWroblewska, and M.F. Kagnoff. 1993. Differential cytokine expression by human intestinal epithelial cell lines: Regulated expression of interleukin-8. Gastroenterology. 105:1689-1697.

34. Dhir, S.P., G.E. Kenny, and J.T. Grayston. 1971. Characterization of the group antigen of Chlamydia trachomatis. Infect. Immun. 4:725-730.

35. Stephens, R.S., M.R. Tam, C.C. Kuo, and R.C. Nowinski. 1982. Monoclonal antibodies to Chlamydia trachomatis: antibody specificities and antigen characterization. J. Immunol. 128:1083-1089.

36. Tribby, I.I., R.R. Friis, and J.W. Moulder. 1973. Effect of chloramphenicol rifampicin, and nalidixic acid on Chlamydia psittaci growing in L cells. J. Infect. Dis. 127:155-163.

37. Cevenini, R., M. Donati, and M. La Placa. 1988. Effect of penicillin on the synthesis of membrane proteins of Chlamydia trachomatis LGV2 serotype. FEMS Microbiol. Lett. 56:41-46.

38. Barbour, A.G., K. Amano, T. Hackstadt, L. Perry, and H.D. Caldwell. 1982. Chlamydia trachomatis has penicillin-binding proteins but not detectable muramic acid. J. Bacteriol. 151:420-428.

39. Eckmann, L., S.L. Reed, J.R. Smith, and M.F. Kagnoff. 1995. Entamoeba histolytica trophozoites induce an inflammatory cytokine response by cultured human cells through the paracrine action of cytolytically released interleukin-1 $\alpha$. J. Clin. Invest. 96:1269-1279.

40. Baggiolini, M., B. Dewald, and B. Moser. 1994. Interleukin-8 and related chemotactic cytokines - CXC and CC chemokines. Adv. Immunol. 55: 97-179.
41. Dinarello, C.A. 1994. Interleukin-1. Adv. Immunol. 25:21-51.

42. Kishimoto, T., S. Akira, M. Narazaki, and T. Taga. 1995. Interleukin-6 family of cytokines and gp130. Blood. 86:1243-1254.

43. Megran, D.W., H.G. Stiver, and W.R. Bowie. 1985. Complement activation and stimulation of chemotaxis by Chlamydia trachomatis. Infect. Immun 49:670-673.

44. Ingalls, R.R., P.A. Rice, N. Qureshi, K. Takayama, J.S. Lin, and D.T. Golenbock. 1995. The inflammatory cytokine response to Chlamydia trachomatis infection is endotoxin mediated. Infect. Immun. 63:3125-3130.

45. Brade, L., S. Schramek, U. Schade, and H. Brade. 1986. Chemical, biological, and immunochemical properties of Chlamydia psittaci lipopolysaccharide. Infect. Immun. 54:568-574.

46. McCormick, B.A., S.I. Miller, D. Carnes, and J.L. Madara. 1995. Transepithelial signaling to neutrophils by Salmonellae: A novel virulence mechanism for gastroenteritis. Infect. Immun. 63:2302-2309.

47. Kaplanski, G., N. Teysseire, C. Farnarier, S. Kaplanski, J.-C. Lissitzky, J.-M. Durand, J. Soubeyrand, C.A. Dinarello, and P. Bongrand. 1995. IL-6 and IL-8 production from cultured human endothelial cells stimulated by infection with Rickettsia conorii via a cell-associated IL- $1 \alpha$-dependent pathway. J. Clin. Invest. 96:2839-2844.

48. Mosley, B., S.K. Dower, S. Gillis, and D. Cosman. 1987. Determination of the minimum polypeptide lengths of the functionally active sites of human interleukins $1 \alpha$ and $1 \beta$. Proc. Natl. Acad. Sci. USA. 84:4572-4576.

49. Birkelund, S., H. Johnsen, and G. Christiansen. 1994. Chlamydia trachomatis serovar L2 induces protein tyrosine phosphorylation during uptake by HeLa cells. Infect. Immun. 62:4900-4908.

50. Rank, R.G. 1988. Role of the immune response. In Microbiology of Chlamydia. A.L. Barron, editor. CRC Press, Boca Raton, FL. 217-236. 